\title{
On the history of the Secchi disc
}

\author{
M. R. Wernand \\ marcel.wernand@nioz.nl
}

Royal Netherlands Institute for Sea Research, Physical Oceanography, PO Box 59, 1790 AB Den Burg, Texel, The Netherlands

The first records on regular, tabulated, measurements of transparency of natural waters are those performed by the German naturalist Adelbert von Chamisso during the Russian "Rurik" Expedition 1815-1818 under the command of Otto von Kotzebue. A standardized method to determine the water clarity (transparency) was adopted at the end of the nineteenth century. This method (lowering a white painted disc into the water until it disappeared out of sight) was described by Pietro Angelo Secchi in II Nuovo Cimento and was published in 1865 . The Austrian scientist Josef Roman Lorenz von Liburnau, experimenting with submersible objects, like white discs, in the Gulf of Quarnero (Croatia) in the eighteen-fifties, well before Secchi started his investigations, questioned the naming of the white disc. However, the experiments performed by Secchi and Cialdi in 1864 on such an intensive scale were never performed before. At the beginning of the twentieth century, water transparency observations by means of a $30 \mathrm{~cm}$ white disc, was named the Secchi-disc method. [D0I: 10.2971/je0s.2010.10013S]

Keywords: Secchi disc, water transparency, history of marine optics

\section{INTRODUCTION}

From the time of Louis Ferdinand de Marsilli (1658-1730) until roughly the beginning of the nineteenth century, sea water was analysed both on its colour and its transparency by visual perception. For a judgement on its transparency sea water was put into a vase and described as misty, turbid or clear accordingly. Throughout history, ship's log, of many ocean explorations, regularly refer to the colour and transparency of seawater.

One of the oldest records describing the transparency of the ocean water (directly connected with its colour) was the one made near Novaya Zemlya by Captain John Wood Jr. (16201704), member of the Royal Society and leader of an expedition in search of the Northeast Passage, before he was shipwrecked which dates back to 1676 . Years later, a narrative of the expedition was published and written down in collaboration with the English naval commander Sir John Narborough (1637-1688). One of the observations [1], looking overboard into the sea and noticing the ocean floor, has been quoted frequently over the past centuries: "We sounded and had 80 Fathoms of Water green Oar, at which time we saw the Ground plain, being very smooth water. The Sea Water, about the Ice and the Land, is very salt, and much saltier than any I ever tasted, and a great deal heavier and I may say the clearest in the World, for I could see the ground very plain in 80 Fathoms water and I could see the shells at the bottom very plain."

From his frigate, "Speedwell" Wood could see shells at the bottom of the sea at a depth of eighty fathoms or $140 \mathrm{~m}$. Probably what he saw were Mya truncata shells (first described by taxonomist Carl Linnaeus (1707-1778) in 1758) [2] on a dark coloured bottom.

It is disappointing that until now Wood's observation never has been confirmed by other oceanographers. Apart from the original paper of Narborough the observation of John Wood can be found in Histoire Générale Des Voyages by Jacques Philibert Rousselot de Surgy (1737-1791) [3] and in Histoire des Naufrages of 1789 [4].

If the surface of the sea is ruffled, or in state of agitation, it is hard to see the objects below by any instrument which is not immersed in the water. To overcome this problem, David Brewster [5] in 1813, invented a small floating telescope for viewing objects underwater (see Figure 1) that was recognized by the Academy of Sciences at Copenhagen for its great practical utility.

Captains and scientists, exploring the sea, noticed the sea's great ability of transmitting sun rays until great depths. To measure and quantify the transparency of the sea, several methods were described during the nineteenth century and the accounts of methods used by captains or scientists are sketched in a chronological manner in the following chapter.

An illustrated example of the Secchi disc is presented in Figure 2. Luksch, onboard the steamer "Pola" crossing the eastern Mediterranean and Red Sea between 1890 and 1898 used this small $45 \mathrm{~cm}$ disk [6]. West of Beirut at $33^{\circ} 47^{\prime} \mathrm{N}$ and $34^{\circ} 8^{\prime} \mathrm{E}$ the disc could be seen at $60 \mathrm{~m}$, in the northern Red Sea until $50 \mathrm{~m}$ and in the south only until $39 \mathrm{~m}$.

\section{HISTORICAL BACKGROUND}

It was already under command of the Russian navigator Otto von Kotzebue (1787-1846) on his first exploration trip (18151818 ) in the Bering Sea and looking for a north-eastern pas- 


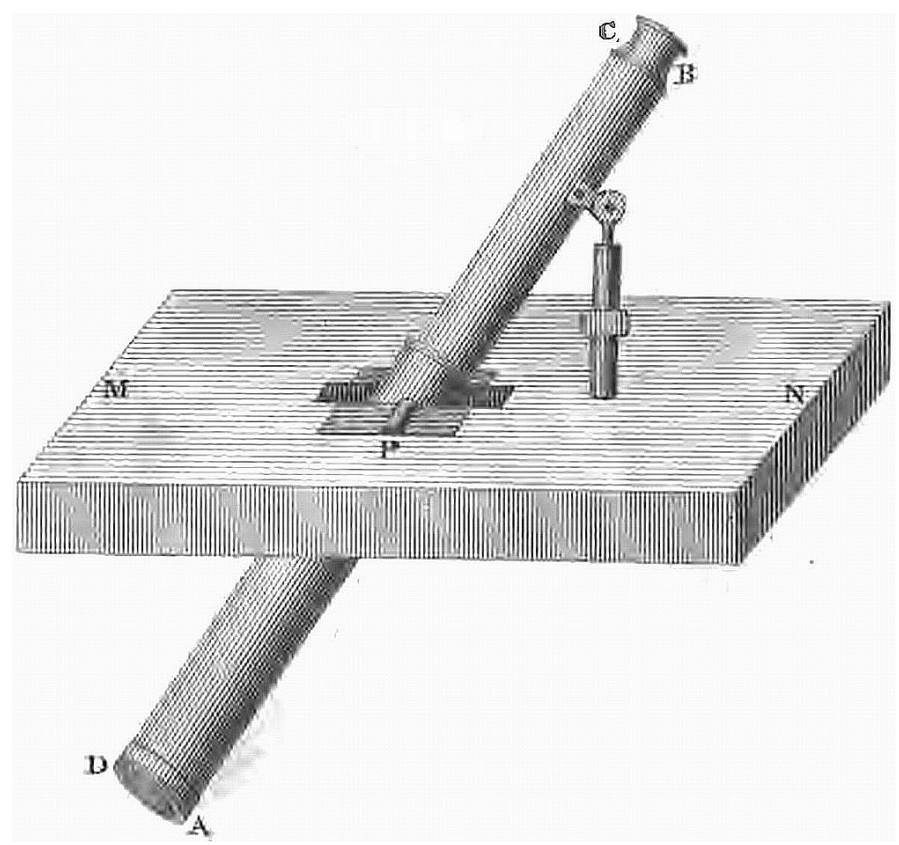

FIC. 1 Brewster's hydraulic tube telescope for viewing objects underwater (1813); "When the apparatus is plunged into the sea, the floating parallelepiped MN will keep the tube $A B C D$ in a vertical plane, and by moving it around the pivot $P$, it may be directed to any object under water or at the bottom" (Reproduced by the author from the original work).

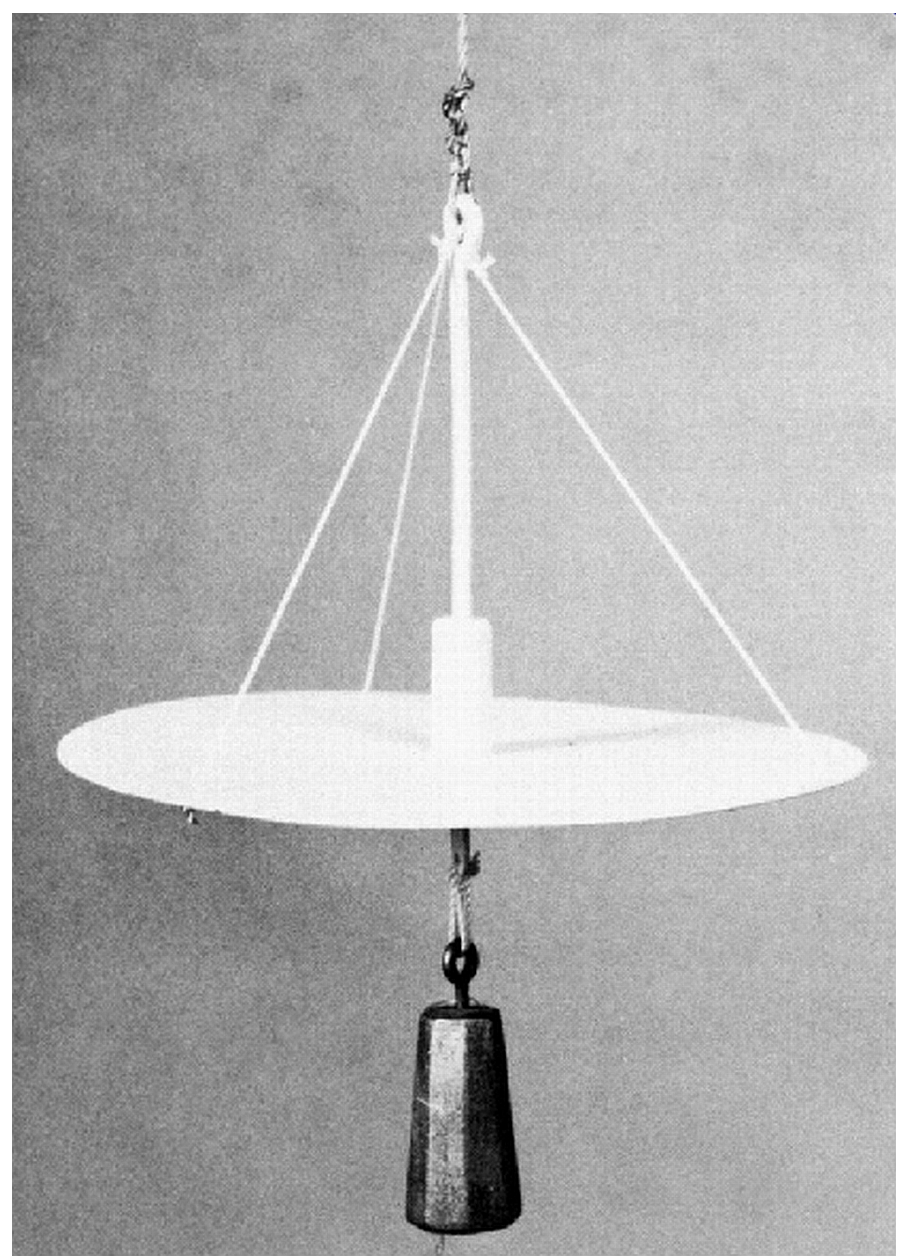

FIG. 2 Luksch polished white painted Secchi disc of $45 \mathrm{~cm}$ in diameter used onboard the "Pola" around 1890. sage that transparency measurements were mentioned. On board the "Rurik", it was the accompanying German writer and naturalist Adelbert von Chamisso (1781-1838) who used a whitened surface attached to the sounding lead to measure the water transparency [7]: "The transparency of the sea water would be easiest measured by letting down a flat surface, fastened to the plumb line, painted white, with stripes, or letters of black, or other colour, on it. For want of this, a white earthen plate, or a board covered with white stuff, might be used. The depth at which the board became invisible or the marks upon it undistinguishable in different waters, would show their relative transparency."

Some of the observations of Adelbert von Chamisso are depicted in Table 1. In the North Pacific, he experienced that a dinner plate could be seen until a depth of 27 fathoms (49 m) [9]: "I observed to-day the transparency of the water with a white plate, and found that it was visible at a depth of twentyseven fathoms: the previous observations of this kind had been made with a piece of red cloth."

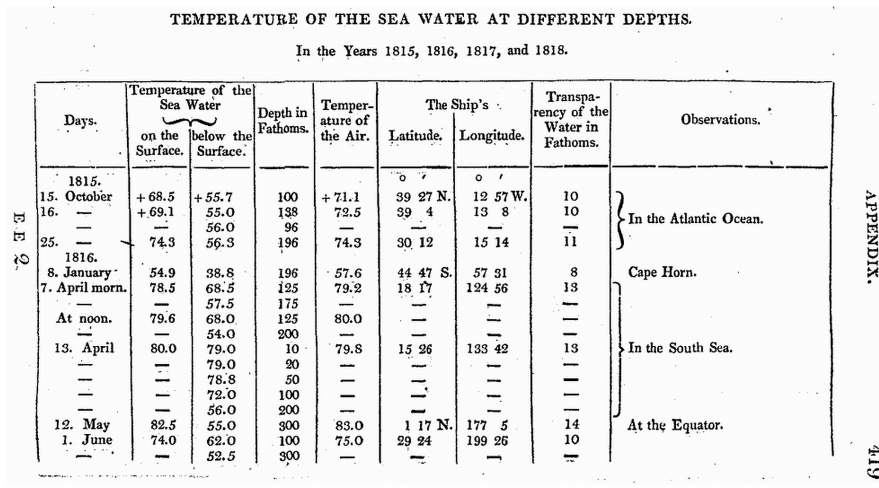

TABLE 1 Observations of the sea surface and air temperature (in degrees Fahrenheit) and of the transparency of the water (in fathoms) measured with a white disc. The observations were collected during the first part of Kotzebue's voyage of discovery during the Atlantic and Pacific crossing.

During a French voyage around the world (1822-1825) under the command of Louis Isidore Duperrey (1786-1865) on the corvette "la Coquille", a white painted plank, with a diameter of 2 feet and an attached weight, was lowered into the water to measure its transparency $[10,11]$. The depths at which the disc disappeared were between $9 \mathrm{~m}$, close to Ascension Island, South Atlantic Ocean and 23 m near Offak, Island of Waigiou, Indonesia (see the French note in Figure 3).

Around 1832, Xavier de Maistre constructed a square iron plate of around $35 \mathrm{~cm}^{2}$, painted white, not to establish the visibility depth but to establish the colour of the sea $[12,13]$ : "I prepared a square sheet of tinned iron, fourteen inches long, painted it white on one side, suspended it horizontally to a cord, and sunk it in a deep place, where the water under the boat, was blue without any mixture of green, watching the effect under the shade of an umbrella which was held over my head. At the depth of twenty five feet, it acquired a very sensible green tinge, and this color became more and more intense to the depth of forty feet when it was of a beautiful green, inclining to yellow; at sixty feet the color was the same, but of a darker shade, and the square Figure of the plate was no longer distinguishable; until at eighty feet, there was apparent only an uncertain glimmering of green which soon disappeared." 


\section{dissemblables. A Offak, dans l'ile Waigiou, par un temps calme et couvert, le 13 septembre, le disque disparut quand il fut descendu de $\mathbf{6}$ mètres ( 55 pieds). Le len- demain 14, le ciel étant serein, on ne cessa de voir le même disque qua à la profondeur de $\mathbf{3} 3$ mètres ( $7^{\circ}$ pieds).}

FIG. 3 Louis Isidore Duperrey (1786-1865). Text as noted, by the commander himself, in a chapter on marine observations published in Annales de chimie et physique (1825).

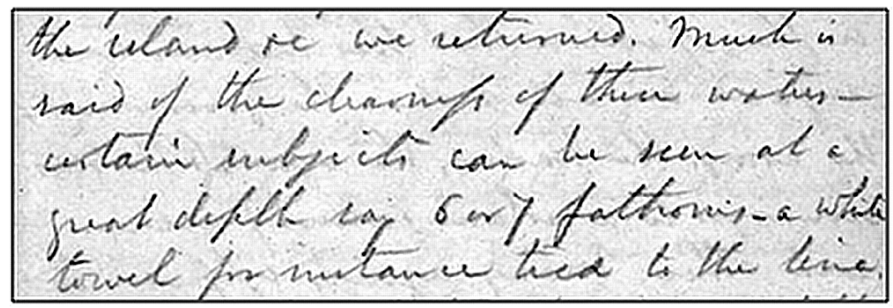

FIG. 4 Notes in Jackson Kemper's diary (1834) during his visit to Green Bay showed a white towel used to determine the transparency of water. Transcription: "Much is said of the clearness of these waters - certain subjects can be seen at a great depth say six or seven fathoms - a white towel for instance tied to the line" (Reproduced from the archives of the Wisconsin Historical Society, USA).

For the determination of the transparency, all kinds of equipment such as plates, tins, kitchen-gear, painted thermometers or copper balls ("diaphanometer", see [14]) were submerged into the water and lowered until they disappeared. Kemper around 1834 [15] used a white towel to measure the clearness of the water (see Figure 4).

The variety of objects used to measure transparency is also illustrated by the remarks of some captains. U.S. Navy Lt. Charles Wilkes (1798-1877) joining an US-squadron on its trip around the world (The Wilkes Expedition between 1838 and 1842) performed water transparency measurements like Navy Captain James Glynn (1800-1871) some years later [16], both using a simple white painted iron pot. During Wilkes trip from Funchal (Madeira) via Porto Praya (Cape Verde Islands) to Rio de Janeiro he observed "pot visibilities" (see Table 2) between $21 / 2$ fathoms and 20 fathoms (4 1/2 $\mathrm{m}$ to $36 \mathrm{~m}$ ) [17]: "First we tried an iron pot, painted white, next we tried a sphere of hoops, covered with white cotton cloth. Then we tried a mere hope, covered with a canvas. At last we took a common white dinner plate. It was good enough."

Captain Auguste Bérard also used a porcelain dinner plate, mounted in a fish net, during the French Arago Expedition in 1845. Passing the South Pacific Wallis Island on July 16 he measured a "dinner plate" disappearance depth of $40 \mathrm{~m}$ [18].

Under command of Samuel Phillips Lee (1812-1897) the transparency of the sea was measured from the U.S. Surveying Brig "Dolphin" by means of lowering white painted foot square blocks [19].

As mentioned before, all kinds of attributes were used to establish the clarity of natural water. From a complete different field of science came Michael Faraday (1791-1867) who, in 1855 , crossed the Thames River on a steamboat. He had subse-
U. S. SHIP VINCENNES

FROM PORTO PRAYA TO RIO DE JANEIRO.

\begin{tabular}{|c|c|c|c|c|c|c|c|c|c|c|c|c|}
\hline \multirow{2}{*}{1838.} & \multirow{2}{*}{$\begin{array}{l}\text { Lat. } \\
\text { North. }\end{array}$} & \multirow{2}{*}{$\begin{array}{l}\text { Long. } \\
\text { West. }\end{array}$} & \multicolumn{3}{|c|}{ THER MOMETERS. } & \multirow{2}{*}{ Barom. } & \multirow{2}{*}{ Hygrom } & \multicolumn{2}{|l|}{ wind. } & \multirow{2}{*}{ Clouds. } & \multirow{2}{*}{ 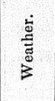 } & \multirow{2}{*}{ Remarks. } \\
\hline & & & Air. & Water. & $\begin{array}{l}\text { Mast. } \\
\text { head. }\end{array}$ & & & Direc. & 气ँّ & & & \\
\hline 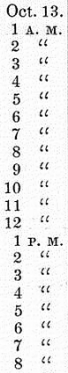 & $9^{\circ} 21^{\prime}$ & $24^{\circ} 11^{\prime}$ & $\begin{array}{l}79^{\circ} \\
80 \\
78 \\
77 \\
79 \\
79 \\
82 \\
82 \\
83 \\
83 \\
84 \\
83 \\
83 \\
81 \\
83 \\
82 \\
84 \\
81 \\
80 \\
80\end{array}$ & \begin{tabular}{|l}
$833^{\circ}$ \\
83 \\
83 \\
82 \\
83 \\
83 \\
83 \\
83 \\
83 \\
83 \\
84 \\
84 \\
85 \\
85 \\
85 \\
85 \\
85 \\
85 \\
84 \\
83
\end{tabular} & $78^{\circ}$ & $30 \cdot 100$ & $84^{\circ} 70^{\circ}$ & $\begin{array}{l}\text { S.W.bys. } \\
\text { Calm. } \\
\text { Var. } \\
\text { Calm. }\end{array}$ & 1 & $\begin{array}{l}\text { Clear. } \\
\text { Nimbi. }\end{array}$ & $\begin{array}{l}\text { c. } \\
\text { c. p. } \\
\text { b. } e . \\
\text { c. } \\
\text { c. u. }\end{array}$ & 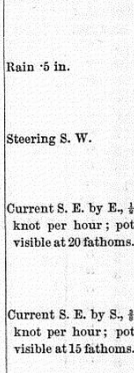 \\
\hline
\end{tabular}

TABLE 2 Part of a meteorological table filled with data collected during the U.S. Exploring Expedition during the years 1838, 1839, 1840, 1841, 1842 under the command of Charles Wilkes (see under remarks on "pot visibility").

quently done good service by calling public attention to what he then observed. Literally he stated [20, 21]: "The appearance and the smell of the water forced themselves at once on my attention. The whole of the river was an opaque pale brown fluid. In order to test the degree of opacity, I tore up some white cards into pieces, moistened them so as to make them sink easily below the surface."

During his 1858 to 1860 investigations in the Gulf of Quarnero (Croatia), Josef Roman Lorenz, later known as Josef Roman Lorenz Ritter von Liburnau, measured the transparency of the sea by lowering a "batho-" thermometer ${ }^{1}$ [22] with a white painted lid (see Figure 5) [23]. During later investigations, for instance in the Halstättersee (Lake in Austria), he used a white painted tin disc of $30 \mathrm{~cm}$ diameter [24]. The naming of the Secchi-disc was especially questioned by Josef Roman Lorenz von Liburnau at the end of the era who himself called the method "the disc system". Literally Lorenz writes in a chapter on limnology [24]: "As substantially different methods are not commonly conceivable one always falls back to one and the same method to establish the boundaries of the visibility under water, I used it in 1858-1860, seven years before Secchi, during my investigations in the Quarnero, without considering it as a memorable invention. However, the procedure became commonly known as the "Secchi System"; I call it "Disc-System"."2

In all mentioned publications thus far, including the one of Lorenz, it was never investigated nor explained why discs were used of an approximate $30 \mathrm{~cm}$ to $35 \mathrm{~cm}$ (1 feet). Perhaps

\footnotetext{
${ }^{1}$ Das Instrument ist bei den Untersuchungen des Verfassers im Quarnerischen Golfe zur Anwendung gekommen, wo es sich um Tiefen von nicht mehr als 60 Faden handelte, also möglichste Einfachheit und leichteste Handhabung verlangt wurden. Translation: During the author's research in the Gulf of Quarnero, the instrument has been used, at depth not over sixty Fathoms, for its simplicity and the ease of handling.

${ }^{2} \mathrm{Da}$ eine wesentlich andere Methode nicht wohl denkbar ist und auf die selbejeder verfallen muss, der sich über die Grenzen der Sichtbarkeit unter Wasser informieren will, habe ich dieselbe als selbverständlich schon 1858-1860, sieben Jahre vor Secchi bei meinen Untersuchungen im Quarnero angewendet, ohne darin eine nennenswerte Erfindung zu erblicken. Es ist nun üblich geworden, dieses Verfahren System Secchi zu nennen; ich nenne es das Scheiben System.
} 


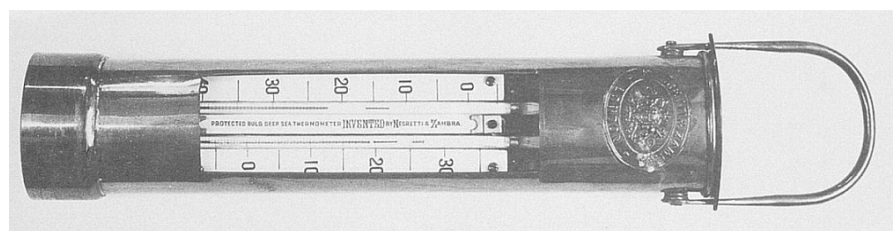

FIG. 5 The so-called "batho-"thermometer with a white painted lid (right). The instrument was used in vertical position in the Adriatic to establish the sea's visibility, next to the temperature.

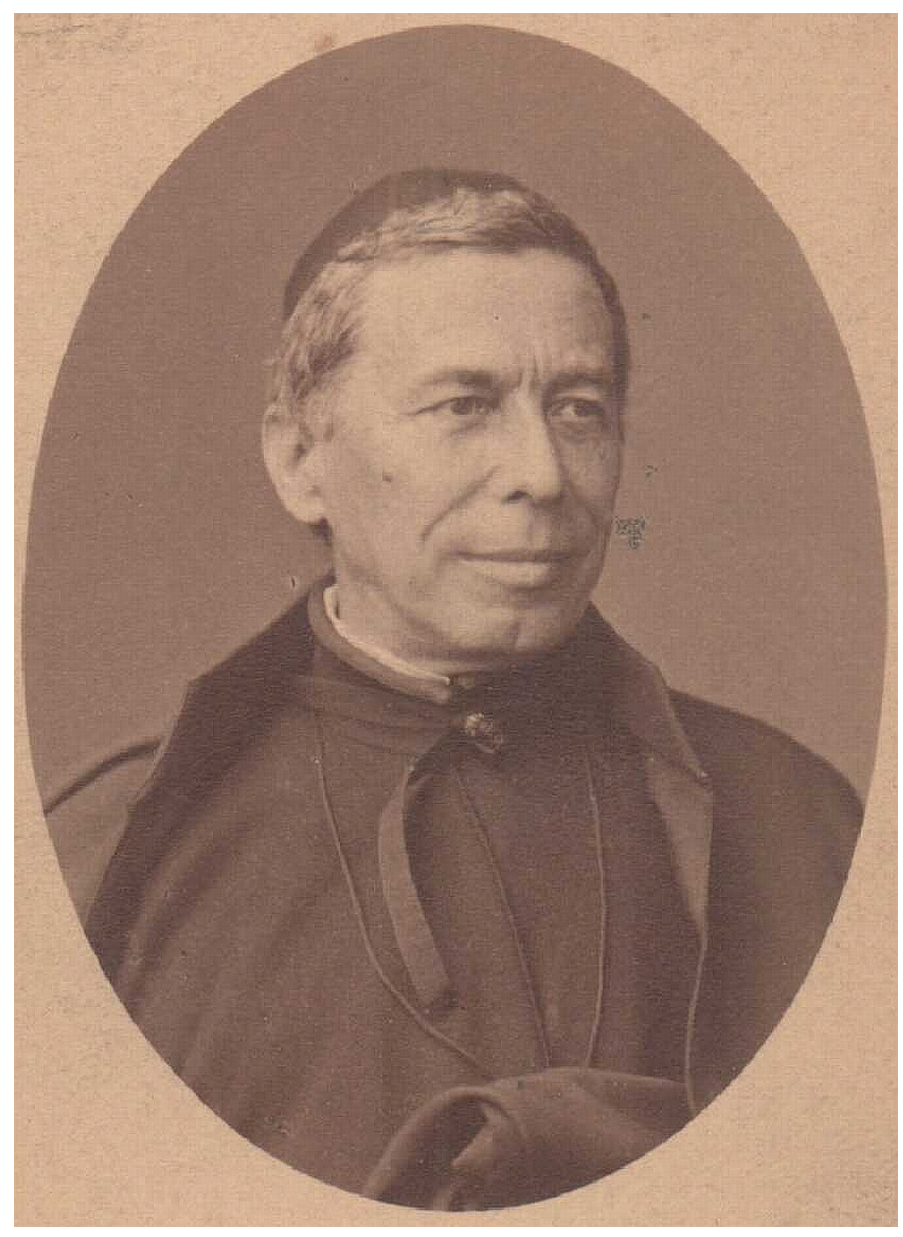

FIC. 6 Padre Pietro Angelo Secchi (1818-1878)

the porcelain dinner plates used on several occasions were close to this diameter.

\section{THE WHITE DISC AS STANDARD}

Two years after Lorenz's 1863 publication on physical properties of the Quarner Gulf, including his transparency observations, an article on the same topic appeared in a weekly magazine of the French Academy of Science. Alessandro Cialdi and Angelo Secchi (see Figure 6) performed transparency measurements in the Tyrrhenean Sea in front of Civitavecchia near Rome. In a barely three pages long article, observations onboard the papal corvette "Immacolata Concezione" and methods to establish the water transparency were described [25] with a brief description of the size, material and colour of the employed discs.

As lots of scientists and captains dealt with the transparency phenomenon of the sea far before Secchi and looking at the published material before and around the time of Cialdi and Secchi, we can still not make it plausible why the method at the end of the nineteenth century became known as the Secchi disc method.

However, looking at forgotten chapters published in the Italian scientific Journal Il Nuovo Cimento in 1865 [26] and in Cialdi's book Sul Ondoso del Mare [27] of 1866, it definitely clarified the naming of the method. In the two identical thirtytwo paged chapters all aspects of transparency disc measurements are described. The colour of the disc, its diameter and the height of the sun are described in relation to its disappearance depth. Furthermore the positions, such as the bow of the ship, from which measurements were performed, were taken into account. In Table 3 an example of the height of the sun and the disappearance depths per disc diameter (grande $=$ large, piccolo $=$ small) are shown. At this point it goes too far to mention all of Secchi's results. But by reading Secchi's original work it became clear why the method finally becomes known as the Secchi-disc method. (Requests for a copy of Secchi's publication in the scientific Journal Il Nuovo Cimento can be made to marcel.wernand@nioz.nl).

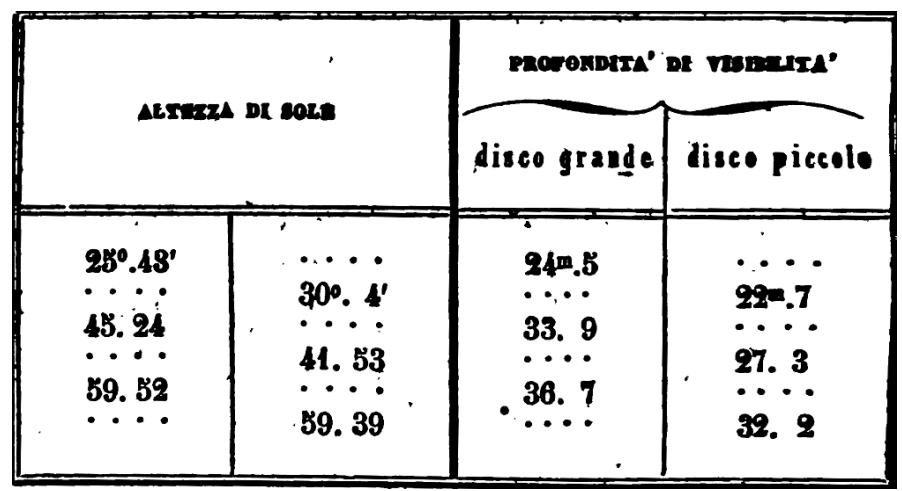

TABLE 3 In an experiment on 21 April 1865, Secchi tabulated the results of the disappearance depths of a small and a large disc used under different sun heights.

\section{POSTSCRIPT}

In 1984 five observers, sailing in the eastern Mediterranean, viewed a marine standard, $40 \mathrm{~cm}$, white Secchi disc through a $20 \mathrm{~cm}$ hole in the "hero platform" (the bucket in which scientists stand while deploying instruments over the side of a research vessel) and determined a depth of $53 \mathrm{~m} \mathrm{[28].} \mathrm{However,}$ two years later this record was broken by Gieskes and three other observers [29] in the Antarctic and the Secchi depth was determined at a depth of $79.5 \mathrm{~m}$. Until the time of writing a world record with French oceanographers following with a Secchi depth of $74 \mathrm{~m}$ observed near Easter Island [30]. A world record Secchi depth has been claimed but we have to bear in mind the observation mentioned at the beginning of this contribution, which is still a robust water visibility record that stands for over 3 centuries: a bottom seen at $146 \mathrm{~m}$ depth by Captain John Wood near Nova Zembla in June 1676. Theoretically, in the purest natural waters, according to calculations of René Dirks [31] the maximum Secchi-disc visibility is between $150 \mathrm{~m}$ and $170 \mathrm{~m}$. 
The late twentieth century has brought us a variety of advanced optical instruments to determine the transparency of sea water electronically. However, the author recommends a reintroduction of the Secchi disc to expand the historical Secchi depth database to facilitate climate change research. One option is to mount a Secchi disc on an instrumental- or CTD frame. Historic Secchi depth data can be retrieved from oceanographic and meteorological databases archived by the United States National Oceanographic Data Centre (NOAANODC). The NODC global oceanographic dataset contains over 400000 Secchi depth observations and belongs to the oldest instrumental datasets quantifying the world seas for over more than a century.

A detailed analysis of the physical and physiological aspects of the Secchi disc can be found in Preisendorfer [32], Graham [33] and Tyler [34] and W. Hou et al. [35]. The basic part of this contribution originates from a paper presented at Ocean Optics 2008 by Wernand which was extended in various ways including the addition of historic illustrations.

\section{ACKNOWLEDGEMENTS}

Gerhard Cadée, Martien Baars, Jeff Zimmerman (Royal Netherlands Institute for Sea Research) and Hans van der Woerd (IVM, Free University Amsterdam) are thanked for their inspiring discussions on the matter.

\section{References}

[1] J. Narborough, J. Tasman, J. Wood, and F. Marten, An Account of Several Late Voyages and Discoveries to the South and North (Samuel Smith and Benjamin Walford, London, 1694).

[2] C. Linnaeus, "Systema naturae per regna tria naturae, secundum classes, ordines, genera, species, cum characteribus, differentiis, synonymis, locis" in Holmiae, 1, 670 (Laurentii Salvii, Stockholm, 1758).

[3] J. P. Rousselot de Surgy, and A. Prévost, Histoire générale des voyages, ou Nouvelle collection de toutes les relations de voyages par mer et par terre, qui ont été publiées jusqu'à présent dans les différentes langues de toutes les nations connues (Didot, Paris, 1759).

[4] Anonymous (M.D.), Naufrages de la frigate Angloise le "Speedwell" sur la côte de la Nouvelle-Zemble, à la pointe de Speedill en 1676 (Histoire des Naufrages ou recueil, Paris, 1789).

[5] D. Brewster, "Description of Instruments for viewing Objects under Water" in on optical instruments for different purposes in which the rays are transmitted through fluids: A treatise on new philosophical instruments, for various purposes in the arts and sciences; with experiments on light and colours, 225-239 (John Murray, London, 1813).

[6] J. Luksch, "Untersuchungen über die Transparenz und Farbe de Seewassers" in Wissenschaftliche Ergebnisse XIX, Expeditionen S.M. Schiff "Pola" im Mittelländischen, Ägäischen und Rothen Meere in den Jahren 1890-1898, Berichte der Commission für Oceanographische Forschungen, Collectiv-Ausgabe aus dem LXIX Bande der Denkschriften Kaiserlichen Akademie der Wissenschafte, A. Forschungen im Rothen Meere, B. Forschungen im Östlichen Mittelmeere, 400-485 (Hof- und Staatsdruckerei, Wien, 1901).

[7] 0. von Kotzebue, "Introduction" in Voyage of discovery into the
South Sea and Beering's Straits, for the purpose of exploring a North-East passage, undertaken in the years 1815-1818, at the expense of His Highness the Chancellor of the Empire, Count Romanzoff, in the ship Rurick, under the command of the lieutenant in the Russian Imperial Navy, Otto von Kotzebue, 1, 81 (Longman, Hurst, Rees, Orme and Brown, London, 1821).

[8] 0. von Kotzebue, "Temperature of the sea water at different depths, in the years $1815,1816,1817$, and 1818 " in Voyage of discovery into the South Sea and Beering's Straits, for the purpose of exploring a North-East passage, undertaken in the years 1815-1818, at the expense of His Highness the Chancellor of the Empire, Count Romanzoff, in the ship Rurick, under the command of the lieutenant in the Russian Imperial Navy, Otto von Kotzebue, 3, 419-424 (Longman, Hurst, Rees, Orme and Brown, London, 1821).

[9] 0. von Kotzebue, "From the St. Lawrence Islands to Guahon" in Voyage of discovery into the South Sea and Beering's Straits, for the purpose of exploring a North-East passage, undertaken in the years 1815-1818, at the expense of His Highness the Chancellor of the Empire, Count Romanzoff, in the ship Rurick, under the command of the lieutenant in the Russian Imperial Navy, Otto von Kotzebue, 2, 227 (Longman, Hurst, Rees, Orme and Brown, London, 1821).

[10] J. L. Gay-Lussac, and F. Arago, "Marées" in Anales de chemie et physique, 30, 362-363 (Chez Crochard, Paris, 1825).

[11] F. Arago, "Marées" in Voyage de la Coquille, Oeuvres Complètes de François Arago, 9, 203 (Gide, Paris, 1857).

[12] X. de Maistre, "Sur la couleur de l'air et des eaux profondes, et sur quelques autres couleurs fugitives analogues" in Optique, 259-278 (Paris, 1832).

[13] X. de Maistre, "On the color of the air and of deep waters, and on some other analogous fugitive colors" translated by J. Ckiscom in The American Journal of Science and Arts, Benjamin Silliman, ed., 26, 68 (E. Hayes, New Haven, 1834).

[14] J. R. Jackson, "Diaphanometer" in What to observe; or the traveller's remembrancer, 468-469 (James Madden at Co., London, 1841).

[15] J. Kemper, Journal of an Episcopalian missionary's tour to Green Bay, 14, 442-443 (Wisconsin Historical Collections 1898, 1834).

[16] A. M. Wells, "On transparency of the ocean (James Glynn)" in Annual of scientific discovery: or, year-book of facts in science and art for 1855, exhibiting the most important discoveries and improvements in mechanics, useful arts, natural philosophy, chemistry, astronomy, meteorology, zoology, botany, mineralogy, geology, geography, antiquities, 200-201 (Gold and Lincoln, Boston, 1855).

[17] C. Wilkes, "Meteorology" in United States Exploration Expedition during the years 1838, 1839, 1840, 1841, 1842, under the command of Charles Wilkes, U.S.N, 11, 22-31 (Sherman, Philadelphia, 1851).

[18] F. Arago, "Notes sur quelques résultats obtenus pendant le voyage du captaine Bérard a la Nouvelle Zélande" in Oeuvres Complètes de François Arago, 9, 487-488 (Gide, Paris, 1857).

[19] S. P. Lee, "January 241852 " in Abstract log of the United States surveying brig "Dolphin" (1851-52), 59, 431 (Tucker, Washington, 1853-1854).

[20] R. A. Brooman, "Polluted state of the Thames" in Mechanics' Magazine, July $7^{\text {th }}$ - December $29^{\text {th }}, 63,28$ (Roberts, Brooman at Co., London, 1855).

[21] G. C. Cadée, "Michael Faraday and his Secchi discs" in Archives of Natural History, 23, 291-0294 (Edinburgh University Press, Edinburgh, 1996). 
[22] J. R. Lorenz, "Ein Tiefenthermometer von mehrfacher hydrographischer Verwendbarkeit" in Kaiserlich-Königlichen Ceographischer Gesellschaft, 6, 178-185, (Abhandlugen, Wien, 1863).

[23] J. R. Lorenz, "Physicalische Verhältnisse und Vertheilung der organismen im Quarnerischen Colfe" in Kaiserlich-Königlichen, 379 (Hof- und Staatsdruckerei, Wien, 1863).

[24] J. R. Lorenz Ritter von Liburnau, "Limnophysik; Durchsichtigkeit" in Mittheilungen der Kaiserlich-Königlichen Geographischen Gesellschaft, 42, 69 (Lechner, Wien, 1898).

[25] A. Cialdi and P. A. Secchi, "Sur la transparence de la mer" in Comptes rendus hebdomadaire de séances de l'Academie des Sciences, 61, 100-104 (Academie des Sciences, Paris, 1865).

[26] P. A. Secchi, "Relazione delle esperienze fatte a bordo della pontificia pirocorvetta Imacolata Concezione per determinare la trasparenza del mare" in Memoria del P.A. Secchi. II Nuovo Cimento Giornale de Fisica, Chimica e Storia Naturale, Ottobre 1864, Published 1865, 20, 205-237 (G. B. Paravia, Torino, 1864).

[27] P. A. Secchi, "Relazione delle esperienze fatte a bordo della pontificia pirocorvetta Imacolata Concezione per determinare la trasparenza del mare" in Sul moto ondoso del mare e su le correnti di esso specialmente su quelle littorali, 258-287 (Comm. Alessandro Cialdi, Roma, 1866).
[28] T. Berman, P. D. Walline, A. Scheller, J. Rothenberg, and D. W. Townsend, "Secchi disc depth record: A claim for the eastern Mediterranean" Limnol. Oceanogr. 30, 447-448 (1985).

[29] W. W. C. Gieskes, C. Veth, A. Woehrmann, and M. Graefe, "Secchi disc visibility world record Shattered" Eos T. Am. Geophys. Un. 68, 123 (1987).

[30] A. Morel, B. Centili, H. Claustre, M. Babin, A. Bricaud, J. Ras, and F. Tièche, "Optical properties of the "clearest" natural waters" Limnol. Oceanogr. 52, 217-229 (2007).

[31] R. W. J. Dirks, On the colour of the sea with reference to remote sensing (Phd Thesis, University of Utrecht, The Netherlands, 1990).

[32] R. W. Preisendorfer, "Secchi disk science: Visual optics of natural waters" Limnol. Oceanogr. 31, 909-926 (1986).

[33] J. J. Graham, "Secchi Disc Observations and Extinction Coefficients in the Central and Eastern North Pacific Ocean" Limnol. Oceanogr. 11, 184-190 (1966).

[34] J. E. Tyler, "The Secchi disc" Limnol. Oceanogr. 13, 1-6 (1968).

[35] W. Hou, Z. Lee, and A. D. Weidemann, "Why does the Secchi disk disappear? An imaging perspective" Opt. Express. 15, 2791-2802 (2007). 